\title{
RECENZJA: RICCARDO BELLANDI, IL CONSIGLIO SUPREMO DI DIFESA. STORIA, ORGANIZZAZIONE, ATTIVITA', IL MULINO, BOLOGNA 2011, SS. 278 \\ DOI: http://dx.doi.org/10.12775/TSP-W.2015.011
}

W prestiżowym wydawnictwie Il Mulino w Bolonii, cztery lata temu ukazała się monografia Riccarda Bellandiego poświęcona Najwyższej Radzie Obrony (dalej: NRO) we Włoszech. W podtytule pracy czytamy, że praca poświęcona jest historii instytucji, organizacji i działalności. Struktura pracy odzwierciedlona w jej spisie treści jest wręcz ,ascetyczna”, bo jego lektura nie daje niestety szczegółowego wyobrażenia o treści poszczególnych fragmentów pracy. Dowiadujemy się tutaj jedynie, że na treść pracy składają się trzy części, a w ich ramach autor wyodrębnia po dwa rozdziały (w części I i II), część trzecia zaś stanowi fragment sam w sobie bez wyodrębnienia w nim osobnych rozdziałów. Do tego dochodzi 13-stronicowy załącznik obrazujący strukturę NRO w kadencjach poszczególnych prezydentów Republiki, składy polityczne NRO oraz problemy będące przedmiotem zainteresowania Rady w rozmaitych okresach jej działalności.

Praca Bellandiego przeszła niemal bez echa we włoskiej doktrynie prawa konstytucyjnego, a staje się przedmiotem zainteresowania obecnie, w dobie napięć, jakie rodzą się w samym państwie włoskim, ale także w okresie wzmożonych napięć na arenie międzynarodowej. Toteż, gdy pojawiły się zwłaszcza napięcia związane w wojną rosyjsko-ukraińską na tle aneksji przez Rosję Krymu, ruszyły też bardziej intensywnie badania problematyki bezpieczeństwa i jej ujęcia w normach prawa w różnych krajach, w tym w Polsce. Staramy się zweryfikować i porównać z naszymi rozwiązaniami i doświadczeniami stany 
normatywne oraz dorobek różnych państw europejskich w sferze ich polityki bezpieczeństwa, instytucjonalizacji działań mających na celu zapewnienie bezpieczeństwa państwa oraz w zakresie kierowania ich siłami zbrojnymi. Z uwagi na rozmaite realne podobieństwa ustrojowych rozwiązań konstytucyjnych Polski i Włoch w sposób naturalny spoglądamy w kierunku Italii, starając się do nich odnieść nasze rodzime problemy i doświadczenia i porównać to, „co nasze”, z dorobkiem Włochów. To sprawiło, że pod „lupę naukową” bierzemy monografię R. Bellandiego o włoskiej NRO.

W I części pracy, w jej pierwszym rozdziale, otrzymaliśmy szczegółową analizę treści art. 87 ust. 9 Konstytucji Włoch. Odnajdujemy tu zatem ciekawe i zarazem zwięzłe zrekonstruowanie i omówienie przebiegu prac nad tym przepisem Konstytucji w Zgromadzeniu Konstytucyjnym w 1947 r. Autor przybliża wiedzę o intencjach ustrojodawcy włoskiego dotyczących sfery kompetencji militarnych prezydenta Republiki i instytucji ustrojowych związanych z zapewnieniem bezpieczeństwa państwu i funkcjonowania jego sił zbrojnych. Autor zwraca uwagę na słabości rozwiązań konstytucyjnych, w tym na fakt, iż twórcy Konstytucji Włoch nie zdobyli się na sformalizowanie centralnej pozycji rządu w określaniu polityki bezpieczeństwa państwa. W ten sposób autor ustala jakby kontekst merytoryczny swoich dalszych rozważań i analiz dotyczących rzeczywistej roli NRO, zwracając m.in. uwagę na semantyczny aspekt nazwy Rady, w odniesieniu do której twórcy konstytucji użyli określnika supremo, a nie jak w przypadku Rady Sądownictwa superiore. Autor powątpiewa w logiczną zasadność użycia określnika supremo wobec organu, któremu nie przyznaje się żadnych znaczących kompetencji decyzyjnych, a jedynie kompetencje czysto konsultacyjne, instrukcyjne i wykonawcze. Bellandi podkreśla wszakże, że w omawianym przypadku Konstytucja z 1947 r. dała życie organowi zupełnie nowemu, bez precedensu w porządku włoskim (chociaż inspiracją była francuska ustawa z doby IV Republiki), przez co zrywała ona z ideą dawnej międzyministerialnej komisji ds. obrony kierowanej przez szefa rządu na rzecz idei rozciągnięcia przewodnictwa NRO na głowę państwa. Powodowało to, że rada ta z samej natury wyzbywała się ryzyka uczynienia z niej organu czysto symbolicznego o swoiście „notarialnym” tylko charakterze. Skoro więc Rada Obrony została osadzona ustrojowo pomiędzy prezydenturą państwa a rolą prezydenta jako zwierzchnika sił zbrojnych oraz została zakwalifikowana de iure jako „najwyższa”, musiała uzyskać jako taka stosowne kompetencje nie tylko konsultacyjne czy instrukcyjne $\mathrm{w}$ sferze definiowania polityki bezpieczeństwa państwa, ale ponadto efektywne jej znaczenie miało ziścić się poprzez złożenie przewodnictwa w NRO w ręce prezydenta Republiki. Wszelkie inne zagadnienia dotyczące ustroju wewnętrznego, zakresu kompetencji, charakteru prawnego 
i usytuowania w systemie konstytucyjnym pozostawiono jako niezdefiniowane i dające się stosować na wiele możliwych sposobów, a więc jako poliwalentne (s. 24). Bellandi ubolewa ostatecznie, że Zgromadzenie Konstytucyjne w 1947 r. nie dokonało wyboru wystarczająco jasnego i że nie podjęło zadania bardziej stanowczego i precyzyjnego zdefiniowania Rady Obrony.

Rozdział II pierwszej części zatytułowany „Ustawa kształtująca” (legge istitutiva) prezentuje rozwiązania przyjęte $\mathrm{w}$ odniesieniu do NRO przez ustawę z 28 lipca 1950 r. nr 624, nota bene jest to ustawa niezmieniona i obowiązująca po dziś dzień. Nawiasem mówiąc, należała ona do pierwszych aktów wykonawczych z lat 50. XX wieku wobec Konstytucji, która wprowadziła zupełnie nowe organy ustrojowe po II wojnie światowej, nieznane dotąd włoskiemu prawu konstytucyjnemu. Określa ona charakter prawny, organizację wewnętrzną, zakres kompetencji i doprecyzowuje usytuowanie ustrojowe rady. Szczególnie ciekawe są rozważania autora ukazujące proces dochodzenia do rozstrzygnięć normatywnych w odniesieniu do NRO w toku prac Zgromadzenia Konstytucyjnego. Ciekawe było zaangażowanie się w przygotowanie projektu ustawy o NRO środowiska naczelnych władz wojskowych Republiki (s. 27 i n.), które bardzo starannie przedstawiło swoje opinie i sugestie w kwestii szczegółowego ukształtowania struktury rady. Na tym tle interesująco prezentowały się propozycje ówczesnego szefa Sztabu Generalnego Sił Zbrojnych Republiki gen. Luigiego Efisio Marrasa, który w styczniu $1948 \mathrm{r}$. przedstawił drobiazgowy projekt dekretu, a w nim detalicznie przygotowany schemat zawierający określenie kompetencji, składu i zasad funkcjonowania NRO. Oczywiście finalna decyzja została złożona w ręce ustawodawcy, który nie tylko nie spieszył się z wykonaniem zadania uchwalenia ustawy, pracując dość leniwie, ale i nie specjalnie liczył się z konsekwencjami wynikającymi z przyjętego w konstytucji modelu formy nowego rządu włoskiego. Projekt wypracowany w parlamencie grzeszył niekonsekwencjami m.in. z punktu widzenia prawa międzynarodowego, ale też pozostawiał nierozwiązanymi liczne delikatne kwestie dotyczące organizacji wewnętrznej i roli samej NRO (s. 29). Przyspieszenie prac parlamentarnych paradoksalnie nastąpiło dopiero pod presją okoliczności związanych z wojną w Korei.

Autor w kolejności omawia problem komponowania składu NRO, mechanizm jej przewodnictwa ze strony głowy państwa i związane z tym problemy natury konstytucyjnej (np. nieodpowiedzialność polityczna Prezydenta Republiki a zagadnienie zakresu jego aktywności jako przewodniczącego NRO wchodzącego merytorycznie w czasie prac rady w sfery zastrzeżone dla wypowiedzi i decyzji rządu itd.). Ponadto autor omawia mechanizmy funkcjonowania wewnątrz rady i role odgrywane przez pozostałych członków rady, w tym znaczenie i zakres aktywności Sekretarza rady. Ciekawie wypadają syntetyczne, chociaż 
dość krytyczne, ustalenia autora pracy dotyczące natury prawnej i usytuowania konstytucyjnego NRO we Włoszech ze wskazaniem na daleko idące niekonsekwencje konstytucyjne w tym zakresie, bo dysponując pewną grupą kompetencji o wręcz dyrektywnym, a nie tylko opiniodawczym charakterze, rada, nie podlegając procedurze odpowiedzialności politycznej przed parlamentem, może de facto rozstrzygać o najważniejszych problemach z dziedziny bezpieczeństwa narodowego oraz przynajmniej deliberować nad problemami organizacji i koordynacji działań wszystkich podmiotów w sferę tę zaangażowanych instytucjonalnie. To zaś może pozostawać w sprzeczności z konstytucją i rodzić problemy na gruncie reguł formy rządów parlamentarnych konstytucyjnie gwarantowanych (s. 41).

W rozdziale III, w części drugiej monografii, zatytułowanym Porzqdek wewnętrzny autor ukazuje procedurę opracowania i przyjęcia regulaminu wewnętrznego NRO na przełomie 1951 i 1952 r. Regulamin ten przetrwał aż do początku lat 90. XX stulecia. Zmiany jego nastąpiły w czasie trwania VI i VII rządu G. Andreottiego. Wówczas wydano dwa dekrety wcześniej przewidziane przez ustawę powołującą do życia NRO z 1950 r. Był to dekret Prezydenta Republiki nr 251 z 1990 r. regulujący organizację i funkcjonowanie wewnętrze oraz strukturę NRO oraz dekret Prezydenta Republiki nr 389 z 1992 r. regulujący szczegółowo strukturę i funkcjonowanie Sekretariatu Rady. Za czasów rządu premiera C. A. Ciampiego, 26 lipca 2000 r. szefowie kancelarii Premiera i Prezydenta Republiki dodatkowo podpisali porozumienie nt. usytuowania i organizacji Biura Sekretariatu NRO. Jest to o tyle ważne, że wspomniane ostatnie akty przyjęte dopiero po wielu latach stanowiły odtąd nareszcie realne uzupełnienie wcześniejszych, niekompletnych rozwiązań normatywnych dotyczących wspomnianej, kluczowej dla bezpieczeństwa państwa instytucji ustrojowej. W kolejnych partiach pracy odnajdujemy ciekawe analizy prawne i realne opisy obecności oraz aktywności w NRO poszczególnych prezydentów Republiki (realnie pięciu, tj. od Gronchiego, Segniego, Saragata, Leonego do Pertiniego), rozmaitych przedstawicieli rządu w tym premierów, szefów Sztabu Generalnego Armii Włoskiej, a wreszcie Sekretarza NRO.

W rozdziale IV, w części II monografii, oraz w rozdziale V, w części III, odnajdujemy niezwykle interesujące opisy i analizy praktyki działania włoskiej NRO w ciągu ostatnich 60 lat, aż do 2009 r., tj. w okresie sprawowania władzy przez wspomnianych już i różniących się jednak stylem sprawowanej władzy prezydentów Republiki. W całym tym okresie poszukiwano też ,ujednoliconego, trwałego modelu dla bytu NRO. Pewną rolę w tym zakresie odegrała powołana z inicjatywy prezydenta Francesca Cossigi przez rząd Giovanniego Gorii w 1988 r. tzw. Komisja prof. Livio Paladina, która zaproponowała uczynienie 
z NRO organu najwyższej... konsultacji dla głowy państwa pozbawionego jednak uprawnień o decyzyjnym charakterze (s. 125). Wprawdzie prezydent Cossiga przystał na takie rozwiązanie, ale kolejny premier G. Andreotti dekretem Prezydenta Republiki nr 251 z 1990 r. dokonał zmiany regulaminu NRO, czyniąc $\mathrm{z}$ rady jedynie organ pomocniczy władzy wykonawczej i poddając ją organizacyjnie i funkcjonalnie swojemu zwierzchnictwu.

Niezwykle ciekawe są opisy i analizy działań NRO w latach 1950-2009 uzupełnione o liczne zestawienia, tabele na stronach 233-262, ukazujące w liczbach liczne aspekty funkcjonowania rady. Waga i znaczenie tej części monografii polega rzeczywiście na tym, że Włochy przez 60 lat, objętych analizami Bellandiego, wielokrotnie musiały stawić czoła rozmaitym groźbom kierowanym z zewnątrz, ale także trudnościom i napięciom o wewnętrznym charakterze, w zakresie bezpieczeństwa państwa, np. miały miejsce starcia z sojusznikami. Za przykład może posłużyć słynny kazus konfliktu Włoch z USA z października 1985 r., gdy Amerykanie przechwycili bez porozumienia z Włochami samolot egipski z terrorystami palestyńskimi, którzy zostali wydani Włochom za to, że uprowadzili włoski statek Achille Lauro, zabijając w trakcie tej operacji obywatela USA (s. 138-173). Amerykanie chcieli przejąć i samodzielnie osądzić sprawców zabójstwa, stąd próba odebrania Włochom jurysdykcji metodą faktów dokonanych i de facto porwanie wydanych terrorystów, i próba uprowadzenia ich do bazy amerykańskiej Sigonella na Sycylii. Konflikt musieli zażegnać osobiście prezydenci obu krajów, korzystając z tzw. gorącej linii telefonicznej dla zapobieżenia zupełnie realnemu przelewowi krwi ${ }^{1}$.

W konkluzji można zgodzić się z ustaleniami Bellandiego, że w rzeczywistości republikańskiej współczesnych Włoch NRO, pomimo bardzo syntetycznego unormowania w Konstytucji i pełnych wątpliwości oraz sprzeczności unormowań regulaminowych z lat 50. i 90. XX w., uzyskała dość trwałą pozycję w porządku ustrojowym Italii. Paradoksalnie słabość regulacji prawnych sprawiała, że NRO działała często dotychczas w oparciu o liczne i elastycznie zmieniane konwenanse czy zwyczaje dostosowywane do zmieniających się uwarunkowań jej funkcjonowania i okoliczności wewnętrznych oraz zewnętrznych. NRO dostosowywała się zatem do kontekstów politycznych i ustrojowych, i w drodze faktów dokonanych modelowała swój kształt. Mogła zatem funkcjonować bardzo dynamicznie, ale i spokojnie, poszerzając swoje oddziaływanie albo je zmniejszając, odrywając bardziej znaczącą albo mniej znaczącą rolę. Dla

${ }_{1}$ Pisałem o tym w monografii Ustrój konstytucyjny wspótczesnych Włoch w aktualnej fazie jego przemian 1989-2004, Toruń 2004,s.241 oraz bardzo szeroko w pracy Prezydent Republiki w systemie ustrojowym współczesnych Włoch, Torun 1991. 
dowodzenia tezy o znaczącej roli NRO chętnie wskazuje się w literaturze prezydenturę G. Gronchiego pomiędzy 1957 a 1960 r., kiedy to uformował on NRO jako prawdziwą i właściwą wręcz radę gabinetową ds. bezpieczeństwa państwa. Trafnie zatem prof. C. Fusaro w 2003 r. określił NRO rodzajem „organu kemeleonicznego", bo jej struktura wewnętrzna i funkcje są już przez lata modelowane przez różne uwarunkowania polityczne i ustrojowe: od roli organu kolegialnego ze specyficznymi kompetencjami i zarazem miejsca konfrontacji pomiędzy głową państwa a rządem, poprzez rodzaj organu uczestnika kreowania linii polityki w zakresie bezpieczeństwa państwa do organu o znaczeniu czysto administracyjnym, od organu z kompetencjami jedynie konsultacyjnymi czy opiniodawczymi do organu zdolnego do realnego wytyczania najważniejszych problemów ze sfery bezpieczeństwa narodowego i narzucania ich rządowi przyjmującemu je jako wiążące go dyrektywy polityczne (s. 177-178). Notyfikowana tu praca z pewnością pokazuje, że tak Prezydent Republiki jako głowa państwa i zarazem przewodniczący NRO oraz sama NRO we Włoszech w omawianym zakresie swoich właściwości nie są li tylko podmiotami czysto symbolicznymi i nie pełnią wyłącznie funkcji honorowych.

Praca napisana jest bardzo ciekawie, przy wykorzystaniu obszernej literatury prawie wyłącznie włoskiej. Jej wartość podnoszą liczne, jak to już zauważono, tabele, zestawienia i podsumowania rozmaitych kwestii ściśle związanych z tytułowym zagadnieniem. Jest to praca, która zainteresuje prawników i politologów oraz wszystkich zajmujących się rozmaitymi aspektami instytucjonalnej problematyki bezpieczeństwa państwa. 